\title{
Dengki, Bersyukur dan Kualitas Hidup Orang yang Mengalami Psikosomatik
}

\author{
Ila Nurlaila Hidayat, Witrin Gamayanti \\ Fakultas Psikologi, Universitas Islam Negeri Sunan Gunung Djati Bandung, Indonesia \\ e-mail: ila.nurlaila@uinsgd.ac.id
}

\begin{abstract}
This study aims to determine the correlation of envy and gratitude to the quality of life of people who experience psychosomatic. The research uses correlational quantitative methods. The research subjects consisted of 106 students who experienced psychosomatic disorders. Measuring instruments used the Islamic Envy Scale (IES) and the Islamic Gratitude Scale (IGS) which are constructed based on the concept of envy and gratitude according to Al-Ghazali, as well as the WHO quality of life scale that was adapted. The results of multiple linear regression tests show that envy and gratitude have a significant correlation to the quality of life. More specifically, envy does not have negative correlation with the quality of life, while gratitude has positive correlation to the quality of life of people who experience psychosomatic.
\end{abstract}

Keywords: envy, gratitude, quality of life, psychosomatic

\begin{abstract}
Abstrak
Penelitian ini bertujuan untuk mengetahui korelasi dengki dan bersyukur dengan kualitas hidup orang yang mengalami psikosomatik. Penelitian menggunakan metode kuantitatif korelasional. Subjek penelitian terdiri dari 106 mahasiswa yang mengalami gangguan psikosomatis. Alat ukur menggunakan Islamic Envy Scale (IES) dan Islamic Gratitude Scale (IGS) yang dikonstruksi berdasarkan konsep dengki dan bersyukur menurut Al-Ghazali, serta skala kualitas hidup WHO yang diadaptasi. Hasil uji regresi linier berganda, menunjukkan bahwa dengki dan bersyukur secara bersama-sama memiliki korelasi signifikan dengan kualitas hidup. Secara lebih khusus dengki tidak berkorelasi negatif dengan kualitas hidup, sedangkan bersyukur berkorelasi positif dengan kualitas hidup orang yang mengalami psikosomatik.
\end{abstract}

Kata Kunci: dengki, bersyukur, kualitas hidup, psikosomatik

\section{Pendahuluan}

Orang yang mengalami psikosomatik seringkali mengeluhkan gangguan fisik yang berulang, misalnya sakit maag, sakit kepala, migraine, darah tinggi atau gatalgatal karena keluhan berulang ini disebabkan oleh stres emosional. Oleh karena itu menjadi penting memperhatikan aspek emosional dalam mengobati orang yang mengalami gangguan psikosomatik. Beberapa penyakit dapat dikategorikan ke dalam jenis penyakit psikosomatik, diantaranya diabetes tipe 2 (Ebrahimi dkk., 2017), yang mana pada penyakit tersebut stres memiliki efek besar terhadap perkembangan, keparahan serta kekambuhannya. Psikosomatik yang sering dialami mahasiswa berdasarkan data wawancara dan observasi yang peneliti lakukan adalah gangguan maag, migraine, gangguan kulit dan pernafasan dalam hal ini adalah asma.

Penelitian Barsky dkk. (2005) menemukan bahwa sebanyak $20 \%$ dari pasien yang datang ke dokter untuk pengobatan primer mengalami gejala fisik yang memiliki penyebab psikologis murni. Penyakit psikosomatik adalah kelainan yang mempengaruhi tubuh dan pikiran. Penyakit ini memiliki dasar emosional yang menyebabkan gejala fisik, dengan demikian stres berat bertanggung jawab atas 90\% dari penyakit ini (Kane, 2009).

Gangguan psikosomatik merupakan masalah kesehatan mental yang muncul 
pada mahasiswa kedokteran di Universitas Nigeria (Chinawa dkk., 2016). Di eropa, Komisi Statistik Eropa (EUROSTAT) mengidentifikasi cardiovascular diseases (CVD) sebagai penyakit yang menempati posisi pertama terkait penyebab kematian pada tahun 2013, yang mana penyakit kardiovaskular ini tergolong sebagai salah satu jenis gangguan psikosomatik (Suciu \& Cristescu, 2017). Diperkirakan bahwa lebih dari $90 \%$ kunjungan pasien ke dokter disebabkan oleh masalah kesehatan yang sebagiannya dipengaruhi oleh stres, dengan demikian gangguan psikosomatik merupakan hal yang sebenarnya telah umum terjadi namun seringkali tidak disadari (Scott, 2018).

Di Indonesia, berdasarkan Riset Kesehatan Dasar tahun 2018 (Kemenkes RI, 2018), memperlihatkan dari 181 orang yang menghadiri Layanan Kesehatan Jiwa Bergerak (Mobile Mental Health Services/MMHS), sejumlah $\quad 49 \%$ mengalami masalah kesehatan jiwa (http://www.depkes.go.id). Informasi lain yang diperoleh dari Kabupaten Sleman Daerah Istimewa Yogyakarta, hasil rekapitulasi data keluhan pasien yang dirujuk ke Psikolog Puskesmas, kebanyakan mengeluhkan berbagai gejala yang tidak jelas dan seringkali berhubungan dengan kondisi fisiknya (Retnowati, 2011).

Pengobatan penyakit fisik seringkali tidak mendapatkan hasil yang diharapkan dikarenakan mengabaikan masalah emosional. Karena intervensi medis seringkali tidak bisa menyembuhkan penyakit pasien secara menyeluruh, karenanya diperkirakan pendekatan lain supaya bisa lebih komprehensif dalam mengatasi penyakit kronis, yaitu intervensi psikologis. Psikoterapi sendiri lebih banyak fokus pada peningkatan fungsi fisik, emosional, sosial, serta pekerjaan dibandingkan dengan fokus pada penyembuhan penyakit itu sendiri (Sturgeon, 2014). Pendekatan psikologis sama pentingnya dengan terapi medis, dan tidak dilihat sebagai alternatif terapi tapi bagian dari terapi yang harus diintegrasikan dengan pendekatan medis untuk membantu pasien bisa sembuh dari penyakitnya (Turk dkk., 2010). Gangguan psikosomatik adalah gangguan fisik (sakit fisik) yang penyebab atau kekambuhannya diperparah oleh kondisi psikologis, misalnya karena stres atau tekanan emosional (Everly \& Lating, 2002).

Permasalahan yang menimbulkan tekanan emosional bisa menjadi stresor bagi tubuh, yang membuat tubuh tidak bekerja dengan baik dan mengganggu organ terlemah dari seseorang. Emosi lain yang bisa menyebabkan stres pada tubuh adalah dengki. Menurut Al-Ghazali (2016) dengki itu adalah salah satu penyakit hati yang emosi dasarnya adalah marah, marah terhadap apapun yang terjadi padanya sebagai dampak dari ketidakridhoannya dalam menerima apa-apa yang datang kepadanya dan hilangnya syukur yang membuat ia semakin merasa sempit hati dan menumbuhkan dengki. Definisi dengki adalah tidak suka melihat orang lain senang, menginginkan sesuatu yang dimiliki orang lain dan kategori dengki yang paling berat adalah keinginan hilangnya kenikmatan dari orang lain. Emosi pada orang dengki, yaitu kebencian, merasa tidak berharga, merasa tidak mampu dan marah, karenanya dengki ini bisa membuat seseorang melakukan tindakan agresi berupa verbal maupun nonverbal, disampaikan secara langsung atau tidak, dalam mengeskpresikan ketidaksukaannya kepada orang yang ia dengki.

Konsep dengki dalam istilah psikologi modern disebut Smith dan Kim (2007) dengan envy, yaitu perasaan tidak senang dan seringkali disertai rasa tersiksa hati yang ditandai dengan adanya perasaan inferior, memusuhi serta membenci keadaan seseorang. Hal lainya dalam dengki ada perasaan depresi dan kebencian (hostility). Semua perasaan itu dasarnya adalah marah karenanya semakin pemarah 
seseorang maka kemungkinan untuk memiliki karakter dengki menjadi besar. Dalam penelitian ini envy akan dibahas berdasarkan konsep Al-Ghazali, ia melihat dengki sampai pada hal yang terhalus, seperti lintasan pikiran. Misalnya terpikir menginginkan sesuatu yang dimiliki orang lain meskipun orang itu tidak bermaksud untuk melenyapkan atau tidak menginginkan kenikmatan itu hilang dari orang yang ia dengki.

Emosi negatif tersebut menimbulkan perasaan kurang tenang, gelisah, cemas dan secara tidak sadar memunculkan perasaan tidak berdaya. Umumnya orang ketika merasa tidak berdaya akan memunculkan agresi yang diekspresikan secara terbuka kepada lingkungan dalam bentuk perilaku atau sebaliknya dia introyeksikan ke dalam dirinya yang memunculkan depresi. Dengki selain disebabkan sombong dan takabur juga tamak. Dampak dengki adalah melukai perasaan sendiri membuat seseorang bisa sedih, merasa susah hati, merasa kurang dan merasa tidak sempurna sebelum memiliki apa yang dimiliki orang lain, tentunya ini menimbulkan ketidakstabilan emosi dan fisik seseorang. Perasaan dengki ini akan dapat mengaktivasi neurological system yang "menyerang" target organ. Semakin besar dengki yang dimiliki seseorang maka kemungkinan gangguan fisik semakin parah juga menjadi lebih besar.

Emosi, relasi sosial serta kesehatan fisik saling memengaruhi secara dinamis, artinya ketika emosi positif dapat meningkatkan persepsi mengenai hubungan sosial yang positif pula, dan akhirnya bisa meningkatkan kesehatan fisik (Kok dkk., 2013). Kesehatan fisik dan mental merupakan dua hal yang sangat berkaitan erat. Ditemukan bahwa kesehatan mental (fisik) di masa lalu berdampak langsung atau tidak secara signifikan terhadap kesehatan fisik (mental) saat ini (Ohrnbergera dkk., 2017).

Emosi negatif bisa dihilangkan dengan rasa syukur, bersyukur adalah kebahagiaan yang muncul baik ketika seseorang sedang membutuhkan sesuatu atau sudah dalam keadaan cukup. Ada perasaan terima kasih, senang, takjub, dan penghargaan terhadap hidup sebagai respon atas sesuatu yang diperoleh baik berupa benda ataupun momen bahagia yang diekspresikan kepada Tuhan, manusia, makhluk lain, dan alam semesta dan menurut orang yang banyak bersyukur akan meningkat kebahagiaannya, well-being dan berkurangnya keluhan/ sakit fisik (Snyder \& Lopez, 2002).

Banyak penelitian yang mengkaitkan antara subjective well-being (SWB) dengan kesehatan fisik dan psikologis artinya semakin tinggi SWB maka semakin sehat secara fisik (Carr, 2004; Compton, 2005; Diener dkk., 2005). Terdapat perbedaan yang cukup signifikan antara konsep gratitude berdasarkan perspektif Psikologi Positif dan Psikologi Islam. Salah satu tokoh besar yaitu Al-Ghazali menjelaskan syukur secara lebih rinci yang diturunkan kedalam, aspek afektif, kognitif, psikomotor, spiritual yang diekspresikan melalui hati, lisan dan tindakan. Dampaknya luar biasa terhadap diri sendiri maupun lingkungan. Orang yang pandai bersyukur adalah orang yang senantiasa berterimakasih atas apapun yang ia peroleh, bukan hanya mengucapkan terimakasih kepada Allah Swt, melainkan juga pandai menjaga hubungan baik dengan orang yang menjadi perantara nikmat itu datang dan terhadap objek rasa syukur. Seperti yang disebutkan dalam sebuah hadis, "barang siapa tidak bersyukur (berterimakasih) kepada manusia, ia tidak bersyukur kepada Allah" (HR. Ar-Tirmidzi). Rasa terimakasih yang diungkapkan melalui lisan, hati dan perbuatan sesuai dengan etika yang ditentukan. Dampaknya adalah perilaku yang lebih baik dan emosi yang lebih positif, karenanya bersyukur diduga bisa meningkatkan kualitas hidup seseorang.

Penelitian mengenai syukur pernah dilakukan oleh Hambali dkk. (2015), peneliti mengatakan bersyukur bisa dilihat 
dalam tiga hal, yaitu pertama, syukur lisan yaitu membicarakan nikmat Allah. Kedua, syukur perbuatan yaitu bekerja hanya untuk dan karena Allah. Ketiga, syukur hati yaitu pengakuan bahwa semua nikmat yang berada pada diri manusia adalah dari Allah. Penelitian tersebut tidak secara khusus membagi sasaran bersyukur seperti yang disampaikan Al-Ghazali yaitu selain kepada Allah juga kepada orang yang menjadi perantara dan kepada objeknya.

Menurut Al-Ghazali (2016), bersyukur (gratitude) akan menambah kenikmatan dan memunculkan rasa senang, menambah rizki dan melunakkan hati yang keras yang bisa menyebabkan dengki. Jadi berdasarkan konsep ini, dapat diambil kesimpulan bahwa ketika seseorang bisa bersyukur maka ia akan terhindar dari dengki. Atau dengan kata lain dengki itu membuat orang tidak bisa melihat rizki atau kenikmatan lain yang ia punya sehingga lupa bersyukur.

Dengki sebagai sumber penyakit fisik bisa diredam dengan bersyukur (gratitude). Orang yang pandai bersyukur dengan sendirinya akan sejahtera dan meningkat kualitas hidupnya. Orang-orang yang mengalami psikosomatik, diduga rasa dengkinya besar, hal itu yang menyebabkan stresor bagi organ terlemahnya yang pada akhirnya bisa menurunkan kualitas hidupnya.

Definisi kualitas hidup/quality of life (QoL) adalah penilaian seseorang terhadap posisinya dalam hidup berkaitan dengan konteks budaya dan sistem nilai dimana mereka berada serta berhubungan dengan tujuan, harapan, standar serta fokus perhatian mereka. Awalnya world health organization (WHO) menetapkan 6 dimensi QoL yaitu physical health, psychological, level independence, social relationship, environment, spirituality/ religion atau personal belief. Kemudian diringkas menjadi 4 domain yaitu, fisik, psikologis, relasi sosial dan lingkungan (WHO, 1997). Berikutnya WHO menggabungkan domain spiritual kedalam domain psikologis. Menurut peneliti, religiusitas harus diukur secara mandiri karena banyak penelitian mengenai kesejahteraan spiritual dan religius terbukti bisa meningkatkan kebahagiaan dan membuat tubuh lebih sehat (Compton, 2005). Alasan lainnya adalah subjek penelitian memiliki agama dan keyakinan. Berdasarkan hal itu, peneliti akan memisahkan kembali aspek religiusitas menjadi salah satu dimensi dalam mengukur kualitas hidup seseorang.

Beberapa penelitian diantaranya dari Zboralski dkk. (2008) membuktikan bahwa permasalahan emosi yang dialami seseorang bisa berdampak pada kualitas hidup orang yang mengalami gangguan psikosomatik. Penelitian ini juga menjelaskan bahwa orang gangguan psikosomatis memiliki QoL yang lebih rendah jika dibandingkan dengan yang sehat. Hal yang sama diungkapkan oleh White dkk. (2006) bahwa orang dengan pulmonary arterial hypertension, kognitifnya terganggu, depresi, cemas dan kualitas hidupnya menurun. Data lain menunjukan orang yang mengalami gangguan peptic ulcer gangguan maag akan menurunkan kualitas hidupnya, karenanya penting untuk mencegah atau mengobati gangguan supaya bisa meningkatkan kualitas hidup mereka (Hafez dkk., 2013).

Dari penelitian yang sudah dijelaskan sebelumnya hanya menghubungkan antara satu tipe gangguan psikosomatik dengan kualitas hidup, misalnya penelitian QoL pada orang yang mengalami urticarial (Silvares dkk., 2011) dan pada orang yang mengalami gangguan peptic ulcer gangguan maag (Hafez dkk., 2013). Dalam penelitian ini, peneliti tidak membatasi jenis gangguan psikosomatiknya karena asumsinya penyebab gangguan psikosomatik salah satunya adalah emosi dengki, kemudian ingin melihat seberapa besar dampak dengki dan bersyukur pada kualitas hidup orang yang mengalami gangguan psikosomatik. 
Berdasarkan pemaparan sebelumnya, terlihat bahwa penyebab psikosomatik adalah emosi negatif yang menjadi stressor bagi organ terlemah, meskipun tidak diuraikan secara spesifik emosi apa yang dimaksud, penelitian lainnya menjelaskan bahwa orang yang psikosomatik kualitas hidupnya menurun. Hasil penelitian tersebut dijelaskan secara terpisah dalam penelitian yang berbeda.

Dalam penelitian ini, peneliti menelusuri korelasi antara emosi dengki (sebagai salah satu jenis emosi negatif yang berkaitan dengan gangguan psikosomatik) serta bersyukur dengan kualitas hidup, sehingga akan lebih tergambar kaitan ketiga variabel tersebut secara lebih utuh agar diketahui seberapa besar korelasi dengki dan bersyukur dengan kualitas hidup orang yang mengalami psikosomatik. Mengingat banyaknya mahasiswa yang mengalami psikosomatik sehingga ia berulangkali harus berobat kedokter tanpa mengenali sumber masalahnya yaitu bukan semata-mata permasalahan fisik saja.

\section{Metode Penelitian}

Metode penelitian menggunakan kuantitatif korelasional. Subjek penelitian sebanyak 106 mahasiswa UIN Sunan Gunung Djati Bandung yang mengalami gangguan psikosomatik. Subjek tersebut diperoleh melalui teknik non-probability sampling jenis purposive sampling, setelah sebelumnya dilakukan proses screening menggunakan inventory untuk mendeteksi gangguan psikosomatik dari Chibnall dan Tait (2015) terhadap 230 mahasiswa. Pada tahap penyusunan alat ukur, peneliti melibatkan pula subjek uji coba sebanyak 219 mahasiswa yang terkategori sebagai psikosomatik dan non psikosomatik.

Untuk mengukur dengki menggunakan skala yang dibuat peneliti dengan mengacu kepada konsep dengki (hasad) menurut AlGhazali (2016). Skala ini diberi nama Islamic Envy Scale (IES), terdiri dari 20 item yang mengukur lima dimensi yaitu: 1) berharap hilangnya nikmat orang lain, sekalipun tidak beralih padanya; 2) berharap hilangnya nikmat orang lain, sekaligus beralih padanya; 3) berharap orang lain tetap dengan keterbatasan pengetahuan ataupun materi; 4) tidak berharap hilangnya nikmat orang lain tetapi berharap mereka tetap setara dengannya; dan 5) berharap dapat menyamai orang lain, tanpa bermaksud hilangnya nikmat mereka. Contoh item: "Melihat kesuksesan yang dicapai orang-orang di sekelilingnya, seringkali A merasa resah dan berpikir bahwa harusnya hanya ia yang mendapat kesuksesan tersebut". Hasil analisis item menunjukkan terdapat 14 item terpakai (.360 - .658), dan dipilih 10 item yang digunakan dalam pengambilan data. Hasil validitas sebesar .367 - .767, sedangkan reliabilitas sebesar .686.

Alat ukur bersyukur juga dikembangkan peneliti mengacu pada konsep bersyukur menurut Al-Ghazali (2016). Skala ini selanjutnya dinamakan Islamic Gratitude Scale (IGS). Terdiri dari tiga dimensi yang mengacu kepada sasaran yang dituju oleh rasa bersyukur itu sendiri yaitu bersyukur kepada Allah, kepada sesama manusia, serta kepada objek. Adapun sub dimensi mengacu kepada jenis dari ungkapan rasa bersyukur yaitu bersyukur dengan hati, dengan lisan, serta dengan perbuatan. Skala ini terdiri dari 81 item, salah satu contohnya: "Dengan apa yang dimiliki saat ini, saya terdorong untuk melakukan hal-hal yang lebih diridhoi Allah". Hasil analisis item menunjukkan terdapat 47 item terpakai (.300 - .509), dan dipilih 44 item yang digunakan dalam pengambilan data. Hasil validitas sebesar .820 - .889, sedangkan reliabilitas sebesar .863 .

Kualitas Hidup diukur dengan skala kualitas hidup yang dibuat WHO (1997), dan dikembangkan oleh peneliti dengan memunculkan kembali aspek spiritual atau religiusitas sehingga terdiri dari 5 aspek yaitu fisik, psikologis, relasi sosial, lingkungan, dan spiritual. Skala ini berisi 
71 item, salah satu contohnya: "Bagaimana anda menilai kemampuan anda untuk bekerja?". Hasil analisis item menunjukkan terdapat 49 item terpakai (.301 - .595). Pada pengambilan data digunakan 52 item, setelah menambahkan beberapa item yang diperbaiki. Hasil validitas sebesar .557 .736, sedangkan reliabilitas sebesar .863.

Data diolah dengan teknik analisis deskriptif (berdasarkan nilai mean) dan inferensial menggunakan analisis regresi linier berganda. Dalam analisis tersebut, dilakukan perhitungan Uji t, Uji $\mathrm{F}$ (Uji Simultan), Koefisien Determinasi, dan persamaan regresi linier berganda.

\section{Hasil Penelitian dan Pembahasan}

\section{Hasil Penelitian}

Hasil perhitungan uji asumsi klasik menunjukkan bahwa: pertama, data berdistribusi normal dan memenuhi syarat uji normalitas untuk analisis regresi linier berganda (data menyebar di sekitar garis diagonal, serta penyebarannya mengikuti garis diagonal tersebut sebagaimana disajikan pada gambar 1); kedua, model regresi yang digunakan bebas dari multikolinieritas (nilai VIF 1.166 dan tolerance .858) maupun heteroskedastisitas (nilai signifikansi > .05 yaitu .610 dan .773); serta ketiga, model regresi sudah linier dan layak digunakan (uji linieritas).

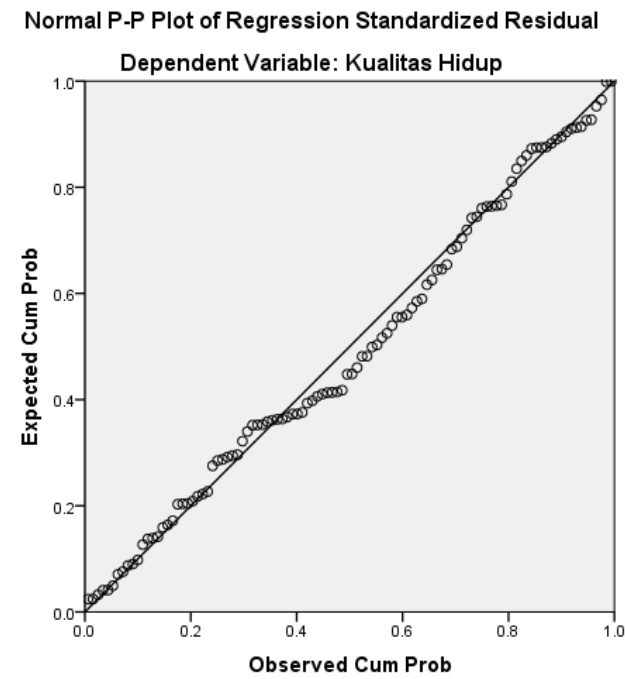

Gambar 1. Hasil uji normalitas
Hasil uji t sebagaimana terdapat pada tabel 1 menunjukkan bahwa nilai signifikansi pada variabel dengki bernilai .879 lebih besar dari alpha $\alpha(.879>.05)$, yang berarti bahwa variabel dengki tidak memiliki korelasi signifikan dengan variabel kualitas hidup pada orang dengan gangguan psikosomatik. Sedangkan nilai signifikansi pada variabel bersyukur bernilai .006 lebih kecil dari alpha $\alpha(.006$ $<$.05), sehingga dapat dikatakan bahwa variabel bersyukur memiliki korelasi signifikan dengan variabel kualitas hidup pada orang dengan gangguan psikosomatik.

Berdasarkan hasil uji $\mathrm{F}$ yang disajikan pada tabel 2, didapatkan nilai $\mathrm{F}$ hitung sebesar 4.420 dengan angka signifikansi $\left(\mathrm{P}_{\text {Value }}\right)$.014. Dengan tingkat kepercayaan 95\% ( $\alpha .05)$, dapat dilihat bahwa nilai $\mathrm{P}_{\text {Value }}$ lebih kecil dari alpha $(.014<.05)$. Berdasarkan perbandingan tersebut dapat disimpulkan bahwa model regresi dalam penelitian ini sudah layak digunakan untuk memprediksi variabel dependen kualitas hidup. Dengan kata lain secara bersamasama variabel independen dengki $\left(\mathrm{X}_{1}\right)$ dan bersyukur $\left(\mathrm{X}_{2}\right)$ memiliki korelasi signifikan dengan variabel dependen kualitas hidup (Y).

Pada tabel 3 dapat dilihat nilai Adjusted $R$ Square sebesar .061. Hasil tersebut dapat diartikan bahwa variabel dengki dan bersyukur dapat menjelaskan variabel kualitas hidup sebesar $6.1 \%$, sedangkan sisanya sebesar $93.9 \%$ variabel kualitas hidup dapat dijelaskan oleh variabel lainnya.

Tabel 1

Hasil Uji $t$

\begin{tabular}{lcc}
\hline Variabel & $\mathrm{T}$ & Sig. \\
\hline Dengki & .152 & .879 \\
Bersyukur & 2.807 & .006
\end{tabular}


Tabel 2

Hasil Uji Signifikansi Simultan (Uji F)

\begin{tabular}{|c|c|c|c|c|c|c|}
\hline & del & Sum of Squares & Df & Mean Square & $\mathrm{F}$ & Sig. \\
\hline \multirow{3}{*}{1} & Regression & 2055.351 & 2 & 1027.675 & 4.420 & $.014^{\mathrm{b}}$ \\
\hline & Residual & 23945.593 & 103 & 232.481 & & \\
\hline & Total & 26000.943 & 105 & & & \\
\hline
\end{tabular}

a. Dependent Variable: Kualitas Hidup

b. Predictors: (Constant), Dengki, Bersyukur

Tabel 3

Hasil Uji Regresi (Koefisien Determinasi)

\begin{tabular}{ccccc}
\hline Model & $\mathrm{R}$ & $R$ Square & Adjusted $R$ Square & Std. Error of the Estimate \\
\hline 1 & $.281 \mathrm{a}$ & .079 & .061 & 15.24734 \\
\hline
\end{tabular}

a. Predictors: (Constant), Dengki, Bersyukur

Tabel 4

Hasil Uji Regresi (Koefisien Regresi)

\begin{tabular}{lcccccc}
\hline \multirow{2}{*}{ Model } & \multicolumn{2}{c}{ Unstandardized Coefficients } & Standardized Coefficients & \multirow{2}{*}{ T } & \multirow{2}{*}{ Sig. } \\
\cline { 2 - 5 } & $\mathrm{B}$ & Std. Error & Beta & & 5.138 & .000 \\
\cline { 2 - 5 } (Constant) & 128.518 & 25.011 & .016 & .152 & .879 \\
1 Dengki & .063 & .414 & .287 & 2.807 & .006 \\
\hline
\end{tabular}

a. Dependent Variable: Kualitas Hidup

Tabel 5

Hasil Uji Regresi (Koefisien Regresi)

\begin{tabular}{ccccccc}
\hline \multirow{2}{*}{ Model } & \multicolumn{2}{c}{ Unstandardized Coefficients } & Standardized Coefficients & \multirow{2}{*}{ T } & \multirow{2}{*}{ Sig. } \\
\cline { 2 - 4 } & $\mathrm{B}$ & Std. Error & Beta & & 6.982 & .000 \\
\hline \multirow{2}{*}{1 (Constant) } & 131.015 & 18.766 & .281 & 2.984 & .004 \\
\hline \multicolumn{2}{c}{ Bersyukur } & .412 & .138 & & &
\end{tabular}

Tabel 4 menunjukkan hasil perhitungan koefisien regresi, namun mengingat hasil uji t yang tidak signifikan pada variabel dengki (tabel 1), maka variabel tersebut dikeluarkan dari model regresi, kemudian prosedur pencarian regresi diulang agar mendapatkan hasil yang lebih pasti sebagaimana disajikan pada tabel 5.

Melihat hasil perhitungan statistik pada tabel 5 diperoleh informasi bahwa nilai konstanta sebesar 131.015 artinya jika variabel dengki dan bersyukur nilainya 0 maka variabel kualitas hidup memiliki nilai positif sebesar 131.015. Terdapat satu variabel yang memiliki korelasi signifikan dengan kualitas hidup orang yang mengalami psikosomatik yaitu bersyukur dengan alpha $(\alpha) .004<.05$ artinya semakin tinggi rasa bersyukur maka semakin tinggi kualitas hidupnya.

Hasil analisis lebih lanjut menunjukkan bahwa diantara ketiga dimensi bersyukur, hanya dua diantaranya yang berkorelasi signifikan dengan kualitas hidup, yaitu dimensi bersyukur kepada Allah dan bersyukur kepada objek sebagaimana disajikan pada tabel 6. Adapun tabel 7 menyajikan secara lebih spesifik bahwa dimensi bersyukur kepada Allah berhubungan signifikan dengan kualitas hidup dan kesehatan secara umum; social relationship; serta spirituality. Sedangkan dimensi bersyukur kepada objek berhubungan signifikan dengan kualitas hidup dan kesehatan secara umum; environment; serta spirituality. Pada tabel 8 dapat dilihat gambaran dari kategori skor yang diperoleh subjek. Pada variabel 
Tabel 6.

Hasil Uji Korelasi Dimensi Bersyukur dengan Kualitas Hidup

\begin{tabular}{lcl}
\hline Dimensi & Pearson Correlation & Sig. \\
\hline Bersyukur kepada Allah & .342 & .000 \\
Bersyukur kepada Manusia & .056 & .569 \\
Bersyukur kepada Objek & .290 & .003 \\
\hline
\end{tabular}

Tabel 7

Hasil Uji Korelasi Dimensi Bersyukur dengan Dimensi Kualitas Hidup

\begin{tabular}{|c|c|c|c|c|c|}
\hline \multicolumn{2}{|l|}{ Dimensi Kualitas Hidup } & $\begin{array}{c}\text { Bersyukur kepada } \\
\text { Allah }\end{array}$ & \multicolumn{2}{|c|}{$\begin{array}{c}\text { Bersyukur kepada } \\
\text { Manusia }\end{array}$} & $\begin{array}{c}\text { Bersyukur } \\
\text { kepada Objek }\end{array}$ \\
\hline \multicolumn{2}{|c|}{ Kualitas hidup dan kesehatan secara umum } & $.241 *$ & \multicolumn{2}{|c|}{.000} & $.198 *$ \\
\hline \multicolumn{2}{|c|}{ Physical } & -.040 & \multicolumn{2}{|c|}{-.139} & -.060 \\
\hline \multicolumn{2}{|l|}{ Psychological } & .090 & \multicolumn{2}{|c|}{-.032} & .043 \\
\hline \multicolumn{2}{|l|}{ Social relationship } & $.420 * *$ & \multicolumn{2}{|c|}{.128} & .180 \\
\hline \multicolumn{2}{|l|}{ Environment } & .181 & \multicolumn{2}{|c|}{.110} & $.219 *$ \\
\hline \multicolumn{2}{|l|}{ Spirituality/ religiousity } & $.499 * *$ & \multicolumn{2}{|c|}{.133} & $.463 * *$ \\
\hline \multicolumn{6}{|c|}{$\begin{array}{l}* * \text {. Correlation is significant at the .01 level (2-tailed). } \\
* . \text { Correlation is significant at the } .05 \text { level (2-tailed). }\end{array}$} \\
\hline \multicolumn{6}{|c|}{$\begin{array}{l}\text { Tabel } 8 \\
\text { Kategorisasi Skor pada setiap Variabel }\end{array}$} \\
\hline Variabel & Mean & Tinggi & Persentase & Rendah & Persentase \\
\hline Dengki & 21.18 & 52 & $49.06 \%$ & 54 & $50.94 \%$ \\
\hline Bersyukur & 135.36 & 44 & $41.51 \%$ & 62 & $58.49 \%$ \\
\hline Kualitas Hidup & 186.83 & 53 & $50 \%$ & 53 & $50 \%$ \\
\hline
\end{tabular}

dengki, persentase subjek pada kategori tinggi maupun rendah relatif seimbang (49.06\% dan 50.94\%), terlebih pada variabel kualitas hidup menunjukkan nilai yang sama yaitu sebesar $50 \%$. Adapun pada variabel bersyukur, cenderung lebih banyak subjek yang berada pada kategori rendah $(58.49 \%)$ dibandingkan kategori tinggi $(41.51 \%)$.

\section{Pembahasan}

Bersyukur memiliki korelasi cukup signifikan dengan kualitas hidup seseorang artinya semakin ia bersyukur maka kualitas hidupnya meningkat. Syukur menurut AlGhazali (2016) adalah ungkapan tulus dari seseorang terhadap Allah Swt. atas karunia yang diberikan kepadanya. Syukur bukan hanya sekedar memuji Tuhan dengan mengatakan "Alhamdulillah" tetapi lebih luas lagi, memperlakukan dengan baik orang yang menjadi perantara sesuai dengan ketentuan yang Tuhan berikan, termasuk menjaga sumber karunia (apapun bentuknya baik uang, barang, ilmu, dan lain-lain) dengan memanfaatkannya sesuai apa yang Allah kehendaki. Jadi dalam syukur itu ada keyakinan hati yang meningkat terhadap Allah Swt., ada perilaku positif yang tampak, merupakan wujud dari keyakinannya terhadap Allah Swt., sehingga dengan bersyukur bukan hanya hubungan kita dengan Allah Swt. menjadi lebih baik melainkan juga dengan orang di sekitar kita, karena pemanfaatan karunia yang Allah Swt. berikan bukan hanya dimanfaatkan untuk kepentingan orang yang menerima rizki saja melainkan juga orang-orang yang ada di sekitarnya. Tidak heran orang yang pandai bersyukur meningkat keyakinan terhadap Allah Swt. dan semakin harmonis dengan lingkungannya. Tentunya hal ini akan meningkatkan kualitas hidup seseorang. Penelitian sebelumnya sudah membuktikan bahwa keyakinan terhadap Tuhan bisa meningkatkan ketenangan dan kebahagiaan. Ini memancing rasa puas terhadap kehidupan yang sedang 
dijalaninya karenanya semakin bersyukur semakin tinggi kualitas hidup seseorang.

Emosi positif dapat membantu meningkatkan kesehatan melalui dua cara yaitu dengan meningkatkan perilaku sehat yang positif ataupun dengan mengubah sumber daya dan proses biofisiologis tubuh (Dunn, 2017). Terkait hasil penelitian ini, dapat dijelaskan bahwa adanya emosi positif berupa bersyukur pada orang yang mengalami psikosomatik setidaknya akan dapat menstimulasi tubuh mereka untuk bekerja pada proses fisiologis yang optimal berdasarkan sumber daya tubuh yang berfungsi secara seimbang (homeostasis).

Hasil penelitian ini sejalan dengan penelitian sebelumnya yang menjelaskan bahwa bersyukur terbukti dapat meningkatkan kualitas hidup dan kesejahteraan psikologis pada pasien kecanduan obat terlarang selama program rehabilitasi (Ghalesefidi dkk., 2019). Dalam penelitian lain dijelaskan lebih spesifik bahwa bersyukur tidak hanya memiliki efek langsung pada kualitas hidup, melainkan juga memiliki efek tidak langsung yaitu melalui stres yang dirasakan serta kesehatan mental (Valikhani dkk., 2019). Penelitian serupa pada subjek mahasiswa Saudi Arabia menegaskan bahwa stres sepenuhnya memediasi hubungan antara bersyukur dengan kepuasan hidup. Artinya tingkat bersyukur yang lebih tinggi secara positif dapat memprediksi tingkat kepuasan hidup yang lebih tinggi pula melalui berkurangnya stres (Yildirim \& Alanazi, 2018).

Penelitian terhadap pasien perawatan paliatif, yaitu pasien yang penyakitnya sudah tidak bereaksi terhadap pengobatan kuratif atau tidak dapat disembuhkan secara medis, ditemukan bahwa pada pasien ini terdapat korelasi positif yang signifikan antara bersyukur dan kualitas hidup yang mereka rasakan (Althaus dkk., 2018).

Penelitian lain pada remaja Guatemala yang memiliki keterbatasan ekonomi, menemukan bahwa envy berkaitan dengan kepuasan hidup yang rendah sedangkan bersyukur berkaitan dengan kepuasan hidup yang lebih tinggi (Poelker dkk., 2017).

Variabel dengki yang semula peneliti duga memiliki korelasi dengan kualitas hidup orang yang psikosomatik ternyata dalam penelitian ini tidak terbukti. Ini juga cukup menarik karena menurut kajian teoretis bahwa seharusnya dengki berkorelasi negatif dengan kualitas hidup. Melihat hasil penelitian, subjek memiliki tingkat dengki yang beragam baik yang tinggi maupun rendah, artinya meskipun subjek penelitian memiliki dengki, namun keberadaan dengki tersebut tidak memiliki korelasi signifikan dalam menurunkan kualitas hidup seseorang.

Secara teoretis, berdasarkan definisi serta dasar struktural syaraf, envy dibedakan menjadi dua jenis yaitu dispositional envy dan episodic envy, yang mana episodic envy lebih sedikit berkaitan dengan dasar struktural syaraf. Dalam istilah lain, dispositional envy disebut sebagai perasaan yang mengakar kuat (chronic feelings) sedangkan episodic envy sebagai pengalaman sekali waktu saja (occasional experiences). Penelitian oleh Xiang dkk. (2017) menunjukkan bukti bahwa dispositional envy menunjukkan korelasi struktural dengan dorsolateral prefrontal cortex (DLPFC) dan superior temporal gyrus (STG) serta memberikan penjelasan netral mengapa individu dengan kecerdasan emosi tinggi menunjukkan envy yang rendah.

Berkaitan dengan kedua jenis envy tersebut, konsep envy yang digunakan dalam penelitian ini, tidak membedakan antara dengki yang bersifat menetap dengan yang sifatnya sementara atau situasional. Dengan demikian bisa jadi skor yang dimiliki subjek dalam penelitian ini lebih mencerminkan dengki yang sifatnya sesaat, makanya tidak berpengaruh terhadap kualitas hidupnya. Selain itu, konsep dengki yang mengacu kepada dimensi menurut Al-Ghazali pada dasarnya meliputi pula dua jenis dengki yaitu yang diperbolehkan serta yang dilarang di dalam 
agama Islam. Dengki yang dilarang ialah yang mengarah pada adanya keinginan akan hilangnya nikmat yang dimiliki orang lain, sedangkan dengki yang diperbolehkan ialah yang mengarah pada adanya keinginan untuk sama dengan orang lain tanpa menginginkan nikmat orang lain hilang, jadi individu hanya bermaksud memacu dirinya agar mampu mencapai halhal positif yang telah dicapai oleh orang lain. Dari segi inipun, tampaknya perlu dipertimbangkan dalam proses konstruksi skala misalnya dengan membedakan kedua jenis dengki tersebut. Dengan demikian alat ukur dengki yang masih belum sempurna dibuat dan diujikan sesuai dengan ketentuan yang ada sehingga belum benarbenar mengukur apa yang hendak diukur. Meskipun untuk penelitian ini peneliti sudah mencoba melakukan prosedur yang seharusnya. Kemungkinan lainnya adalah subjek merupakan mahasiswa muslim yang mengetahui bahwa dengki itu tidak dibenarkan sehingga terdorong untuk menjawab dengan jawaban yang bersifat normatif.

Beberapa keterbatasan dalam penelitian ini diantaranya, pertama, penggunaan alat ukur dengan konstruk teori baru yaitu pada variabel dengki dan bersyukur, untuk hasil yang optimal idealnya menggunakan analisis item berdasarkan model EFA (exploratory factor analysis) namun pengujian tersebut mempersyaratkan jumlah subjek yang lebih banyak. Dalam penelitian ini untuk uji coba alat ukur peneliti hanya melibatkan jumlah subjek sebanyak 219 orang dengan kategori psikosomatik dan non psikosomatik. Adapun subjek penelitian sebenarnya, dari 230 orang yang dilakukan assessment hanya diperoleh sebanyak 106 orang yang memenuhi kriteria sebagai individu yang mengalami psikosomatik. Kedua, dalam teknis pengambilan data uji coba alat ukur, kurang memperhatikan pengaturan waktu bagi subjek dalam mengisi setiap skala, mengingat variabel dan item yang diujikan cukup banyak. Ketiga, sebagai alat ukur yang baru, pada skala envy tidak dilakukan nomological test yaitu membandingkan dengan alat ukur envy yang sudah ada, sehingga dapat dipastikan bahwa alat ukur envy baru ini cukup setara dengan alat ukur sebelumnya.

\section{Simpulan}

Hasil penelitian menunjukkan beberapa simpulan bahwa kedua variabel yaitu dengki dan bersyukur memiliki korelasi yang signifikan dengan kualitas hidup orang yang mengalami gangguan psikosomatik. Apabila dibandingkan secara tersendiri, dapat terlihat jelas bahwa bersyukur menunjukkan korelasi positif yang signifikan dengan kualitas hidup, yang berarti jika seseorang yang mengalami psikosomatik semakin mampu bersyukur maka semakin meningkat pula kualitas hidupnya. Individu dapat melatih diri dengan bersyukur dalam menyikapi setiap pengalaman hidup sehari-hari sehingga stressor pemicu psikosomatik dapat diatasi secara bertahap. Adapun dengki tidak terbukti memiliki korelasi negatif yang signifikan dengan kualitas hidup, artinya untuk subjek penelitian ini dengki tidak menurunkan kualitas hidupnya.

\section{Daftar Pustaka}

Al-Ghazali. (2016). Ihya ulumuddin. Bandung: Marja.

Althaus, B., Borasio, G. D., \& Bernard, M. (2018). Gratitude at the end of life: A promising lead for palliative care. Journal of Palliative Medicine, 21(11). https://doi.org/10.1089/jpm.2018.0027.

Barsky, A. J., Orav, E. J.., \& Bates, D. W. (2005). Somatization increases medical utilization and costs independent of psychiatric and medical comorbidity. Archives of General Psychiatry, 62(8):903-10. DOI: 10.1001/archpsyc.62.8.903.

Carr, A. (2004). Positive psychology: The science of happiness and human 
strength. New York: BrunnerRoutledge.

Chibnall, J. T. \& Tait, R. C. (2015). The psychosomatic symptom checklist revisited: Reliability and validity in a chronic pain population. Journal of Behavioral Medicine, 12, (3), 297-307. DOI: $10.1007 / \mathrm{BF} 00844873$.

Chinawa, J. M., Nwokocha, A. R. C., Manyike, P. C., Chinawa, A. T., Aniwada, E. C., \& Ndukuba, A. C. (2016). Psychosomatic problems among medical students: A myth or reality? International Journal of Mental Health Systems, 10(72). doi: 10.1186/s13033-016-0105-3

Compton, W. C. (2005). Introduction to positive psychology. Belmont, CA: Thomson/ Wadsworth.

Diener, E., Lucas, R. E., \& Oishi, S. (2005). Subjective well-being: The science of happiness and life satisfaction. Handbook of Positive Psychology. New York: Oxford University Press.

Dunn, D. S. (2017). Positive psychology: Established and emerging issues. New York: Routledge Taylor \& Francis Group.

Ebrahimi, L., Masoumi, M., Hojjati, A., Firozjaie, R. A., \& Abdi, M. (2017). Comparing the quality of life and emotional intelligence among patients with psychosomatic disease (type 2 diabetes) and healthy individuals. NeuroQuantology, 15(3), 12-19. doi: 10.14704/nq.2017.15.3.1097.

Everly, Jr. G. S. \& Lating, J. M. (2002). A clinical guide to the treatment of the human stress response, second edition. New York: Kluwer Academic Publishers.

Ghalesefidi, M. J., Maghsoudi, J., \& Pouragha, B. (2019). Effectiveness of gratitude on psychological well-being and quality of life among hospitalized substance abuse patients. Electronic Journal of General Medicine, 16(2):em128.

DOI: https://doi.org/10.29333/ejgm/94091.

Hafez, A. A., Tavassoli, E., Hasanzadeh, A., Reisi, M., Javadzade, S. H., \& Imanzad, M. (2013). Quality of life in peptic ulcer patients referring to AlZahra Hospital of Isfahan Iran. Gastroenterology and Hepatology from Bed to Bench, RIGLD, Research Institute for Gastroenterology and Liver Diseases.

Hambali, A., Meiza, A., \& Fahmi, I. (2015). Faktor-faktor yang berperan dalam kebersyukuran (gratitude) pada orangtua anak berkebutuhan khusus perspektif psikologi islam. Psympathic, Jurnal Ilmiah Psikologi, 2(1), 94-101.

Kane, P. P. (2009). Stress causing psychosomatic illness among nurses. Indian Journal of Occupational and Environmental Medicine, 13(1), 28-32. doi: $10.4103 / 0019-5278.50721$.

Kementerian Kesehatan (Kemenkes) Republik Indonesia. (2018). Hasil Utama Riskedas 2018. Badan Penelitian dan Pengembangan Kesehatan.

Kementerian Kesehatan Republik Indonesia. (2019). Layanan kesehatan jiwa bergerak ramaikan pameran rakerkesnas. Retrieved from http://www.depkes.go.id pada 23 Februari 2019.

Kok, B. E., Coffey, K. A., Cohn, M. A., Catalino, L. I., Vacharkulksemsuk, T., Algoe, S. B., Brantley, M., \& Fredrickson, B. L. (2013). How positive emotions build physical health: Perceived positive social connections account for the upward spiral between positive emotions and vagal tone. Psychological Science, 24(7), 1123-1132. DOI: $10.1177 / 0956797612470827$.

Neuman, W. L. (2000). Social research methods: Qualitative and quantitative approaches. Boston: Allyn and Bacon.

Ohrnbergera, J., Ficherab, E., \& Suttona, M. (2017). The relationship between 
physical and mental health: A mediation analysis. Social Science \& Medicine, 195(2017), 42-49.

Parrot, W. G. \& Smith, R. H. (1993). Distinguishing the experiences of envy and jealousy. Journal of Personality and Social Psychology, 64(6), 906920.

Poelker, K. E., Gibbons, J. L., Maxwell, C. A., \& Elizondo-Quintanilla, I. L. (2017). Envy, gratitude, and well-being among Guatemalan adolescents with scarce economic resources. International Perspectives in Psychology: Research, Practice, Consultation, 6(4), 209-226. http://dx.doi.org/10.1037/ipp0000076

Retnowati, S. (2011). Psikolog puskesmas: Kebutuhan dan tantangan bagi profesi psikolog klinis Indonesia. Yogyakarta: Universitas Gadjah Mada.

Santoso, S. (2012). Aplikasi SPSS pada statistik parametrik. Jakarta: PT. Elex Media Komputindo.

Scott, E. (2018). How to handle a stressrelated psychosomatic illness. Retrieved from https://www.verywellmind.com/howto-handle-psychosomatic-illness3145090 pada 23 Februari 2019.

Silvares, M. R. C., Fortes, M. R. P., \& Miot, H. A. (2011). Quality of life in chronic urticaria: A survey at Public University Outptient Clinic, Botucatu (Brazil). Rev Assoc Med Bras, 57(5), 565-569.

Smith, R. H. \& Kim, S. H. (2007). Comprehending envy. Psychological Bulletin, 133, 46-64.

Snyder, C. R. \& Lopez, S. J. (2002). Handbook of positive psychology. New York: Oxford University Press.

Sturgeon, J. A. (2014). Psychological therapies for the management of chronic pain. Psychology Research and Behavior Management, 10(7), 115-24. doi: 10.2147/PRBM.S44762.

Suciu, M., \& Cristescu, C. (2017). Psychosomatic interrelations in cardiovascular diseases and their consequences on patient's quality of life. Retrieved from http://dx.doi.org/10.5772/intechopen.6 9699.

Turk, D. C., Audette, J., Levy, R. M., Mackey, S. C., \& Stanos, S. (2010). Assessment and treatment of psychosocial comorbidities in patients with neuropathic pain. Mayo Clinic Proceedings, 85(3 Suppl), S42-S50. doi: $10.4065 / \mathrm{mcp} .2009 .0648$

Valikhani, A., Ahmadnia, F., Karimi, A., \& Mills, P. J. (2019). The relationship between dispositional gratitude and quality of life: The mediating role of perceived stress and mental health. Personality and Individual Differences, 141, 40-46. https://doi.org/10.1016/j.paid.2018.12. $\underline{014}$

White, J., Hopkins, R. O., Glissmeyer, E. W., Kitterman, N., \& Elliott, C. G. (2006). Cognitive, emotional, and quality of life outcomes in patients with pulmonary arterial hypertension. Respiratory Research, Doi: 10.1186/1465-9921-7-55.

World Health Organization (WHO). (1997). Programme on mental health: WHOQOL measuring quality of life. Division of Mental Health and Prevention of Substance Abuse.

World Health Organization. (2001). The world health report 2001, mental health: new understanding, new hope. 1211 Geneva 27, Switzerland.

Xiang, Y., Zhao, S. Wang, H., Wu, Q., Kong, F., \& Mo, L. (2017). Examining brain structures associated with dispositional envy and the mediation role of emotional intelligence. Scientific Reports, 7:39947. DOI: 10.1038/srep39947.

Yildirim, M., \& Alanazi, Z. S. (2018). Gratitude and life satisfaction: Mediating role of perceived stress. International Journal of Psychological 
Studies, $\quad$ 10(3), 21-28. doi:10.5539/ijps.v10n3p21.

Zboralski, K., Florkowski, A., Bogusz-

Talarowska, Marian, M., \& Piotr, G. (2008). Quality of life and emotional functioning in selected psychosomatic diseases. Postepy Hig Med Dosw. (Online), 2008(62), 36-41. 
Psympathic, Jurnal Ilmiah Psikologi Juni 2020, Vol. 7, No. 1, Hal. : 79-92 